\title{
«Lo que nos dejaron nuestros padres, nuestros abuelos»: retórica y praxis procesal alrededor de los usos y costumbres indígenas en la Nueva España temprana
}

\author{
por
}

\section{Caroline Cunill ${ }^{1}$}

Ecole des Hautes Etudes en Sciences Sociales, París
Rossend Rovira Morgado²

Universidad Autónoma de Madrid

El presente trabajo tiene como objetivo explorar las múltiples significaciones que revistió el concepto «usos y costumbres» indígenas en el contexto de reorganización cultural y politica que el centro de México y Yucatán sufrieron en el siglo XVI. Para ello, se analiza un amplio abanico de fuentes, como diccionarios coloniales, manuales pastorales y de adoctrinamiento misionero, juicios y ordenanzas para el gobierno de tales pueblos de indios. Se concluye que el alto grado de flexibilidad conceptual y práctica de esta figura jurídica contribuiría tanto a consolidar el dominio colonial como a refrendar algunas reivindicaciones de las autoridades nativas.

Palabras Clave: usos y costumbres; pueblos autóctonos; cultura jurídica colonial; México central; Yucatán.

Cómo Citar Este Artículo / Citation: Cunill, Caroline y Rovira Morgado, Rossend, “«Lo que nos dejaron nuestros padres, nuestros abuelos»: retórica y praxis procesal alrededor de los usos y costumbres indígenas en la Nueva España temprana", Revista de Indias, LXXXI/282 (Madrid, 2021): 283-313. https://doi.org/10.3989/revindias.2021.008.

1 cunillcaroline@gmail.com, ORCID iD: https://orcid.org/0000-0003-3391-9550

2 rroviramorgado@hotmail.com, ORCID iD: https://orcid.org/0000-0002-1995-0298 de uso y distribución Creative Commons Reconocimiento 4.0 Internacional (CC BY 4.0). 


\section{INTRODUCCIÓN}

En su reciente enmienda legislativa del año 2018, la Constitución Política de los Estados Unidos Mexicanos reglamenta, en el Artículo 2. ${ }^{\circ}$, que «son comunidades integrantes de un pueblo indígena aquellas que formen una unidad social, económica y cultural, asentadas en un territorio y que reconocen autoridades propias de acuerdo con sus usos y costumbres $\iota^{3}$. Más allá de los actuales debates académicos que la Carta Magna mexicana suscita en materia de ciencia e historia del derecho, antropología cultural, politología o filosofía indigenista ${ }^{4}$, es un hecho que la presencia de los «usos y costumbres» en la narrativa constitucional mexicana contemporánea hunde sus raíces en la cultura jurídica novohispana. Es sabido que los conceptos legales de la Antigüedad Clásica, la teología política agustiniana, la filosofía tomista, el derecho canónico, los decretos reales castellanos, así como las fuentes de jurisprudencia civil del conjunto de los reinos cristianos de la Península Ibérica fueron invocados con frecuencia en la praxis legal que emanó tanto del Consejo de Indias como de las audiencias americanas ${ }^{5}$. De este modo, tópicos tales como el iustum dominium, la jurisdicción y los usos y costumbres aparecieron no sólo en la legislación indiana, sino también en los discursos que circularon en los tribunales novohispanos.

Bien es cierto que la forma en que los usos y costumbres fueron adaptados y aplicados a las prácticas sociales de los pueblos indígenas de América fue analizada por distintos especialistas, principalmente desde la perspectiva de la historia del derecho ${ }^{6}$. En las últimas décadas, también se ha prestado atención al reajuste estratégico y apropiación cultural del concepto por parte de los actores indígenas y sus representantes legales en sus prácticas procesales ${ }^{7}$. El presente trabajo se sitúa en la frontera entre aquellas dos tradiciones historiográficas y trata de reconciliarlas a través del análisis comparado de un amplio abanico de fuentes del siglo XVI, que van desde los diccionarios coloniales y los manuales pastorales o de adoctrinamiento misionero hasta las cédulas reales, las ordenanzas para el gobier-

${ }^{3}$ Constitución Politica de los Estados Unidos Mexicanos. Diario Oficial de la Federación 5 de febrero de 1917. Última reforma DOF 29 de enero de 2016: 2. Consultado en http:// www.ordenjuridico.gob.mx/Constitucion/cn16.pdf (fecha de consulta: 13-04-2019).

${ }^{4}$ Giraudo, 2007: 39-48. Aragón Andrade, 2007: 9-26. Jiménez Bartlett, 2008: 247-270. Meccarelli, 2016.

${ }^{5}$ Hernando Sánchez, 1996. Canet Aparisi, 2009. Luque Talaván, 2003. Hesles Bernal, 2005.

${ }^{6}$ Manzano Manzano, 1967: 13-64. Tau Anzoátegui, 1973: 115-192. Menegus Bornemann, 1992: 151-159. Herzog, 2013: 303-321; 2021: 1-53.

7 Yannakakis, 2010: 137-173. Premo, 2014: 355-379. Muñoz Arbeláez, 2015. Puente Luna y Honores, 2016: 11-47. 
no de los pueblos de indios y varios juicios en los que estuvieron involucrados actores indígenas del centro de México y de Yucatán. Se arguye que el concepto de «usos» sirvió para despojar de su valor legal a los sistemas normativos autóctonos (tanto los de origen prehispánico como los que se iban fraguando a raíz del contacto), mientras que el de «costumbre» abrió una vía de acceso (controlado por agentes externos a los pueblos de indios) al retorno de algunas prácticas nativas hacia la legalidad colonial. Aunque el concepto de los usos y costumbres fue empleado, en algunas ocasiones, para refrendar las reivindicaciones de las autoridades autóctonas, consideramos que su ambigüedad (de cara al registro escrito, entre otros aspectos) y alto grado de flexibilidad formaron parte de los mecanismos de dominación colonial. En este contexto, cabe preguntarse a qué remitían expresiones como «lo que nos dejaron nuestros padres, nuestros abuelos» ${ }^{8}$.

\section{LOS USOS Y COSTUMBRES EN EL ORDEN NORMATIVO HISPANO}

Como es sabido, los conceptos de usos y costumbres proceden de un acervo jurídico de raigambre grecolatina. Cicerón consideró la consuetudo como «la segunda naturaleza» del hombre ${ }^{9}$ y, en el Digesto, el emperador bizantino Justiniano asentó que «la costumbre inmemorial con razón se guarda como ley..., también obligará con razón a todo aquello que, sin constar por escrito, aprobó el pueblo...; también está legítimamente recibido que se deroguen las leyes..., por el no uso, por tácito consentimiento de todos» ${ }^{10}$. Los usos y costumbres estuvieron, asimismo, atestiguados como fuentes de derecho en el ordenamiento jurídico castellano medieval ${ }^{11}$. Y es que, como

${ }^{8}$ Carta de los principales de México, Ciudad de México, 23 de diciembre de 1554, Archivo General de Indias, Sevilla (AGI), México, leg. 158, citado en León-Portilla, 2001: 249.

${ }^{9}$ Marco Tulio Cicerón, citado por Reynolds, 1988. Cabe señalar que la consuetudo se asimilaba a la mos, el conjunto de prácticas sociales y géneros de vida que referían a la rectitud en el comportamiento o moralidad. Schiller, 1978: 258 y ss. Se suele considerar que consuetudo y mos son equiparaciones en latín del término griego éthos -žcos, $\tilde{\eta} \theta 0 \varsigma_{-}$, presente en la literatura aristotélica. Pérez-Delgado, 2000: 14-15. Mas Torres, 2003: 262 y ss. Alberte González, 1987: 117-128.

${ }^{10}$ Digesto, libro I, título 3, § 1 [533 d.C.], citado por Vicente, 1878: 44. Normalización de la ortografía por los autores. Bonmatí Sánchez, 1988: 343-346. Brinton, 1983: 167-184.

11 Miceli, 2012: 73-106. Tradiciones jurídicas consuetudinarias en otros territorios cristianos peninsulares durante el Medioevo fueron los Usatges de Barcelona (1150) y los Costums de Tortosa (1272), en Cataluña; los Costums $i$ furs de la ciutat i regne de València (1239, 1261) y la Compilatio Maior (1247-1252), en Aragón; y el Fuero de Estella (1164), en Navarra. Es probable que la obra legislativa justinianea del siglo VI llegase a la futura Corona de Castilla por herencia visigoda, pues tanto en la obra Etymologiarum de Isidoro de Sevilla (ca. 630 d.C.) como en la Lex Visigothorum o Liber Iudiciorum (ca. 654 d.C.) - antecedente 
recuerda Francisco Quijano, tanto en el derecho romano como en el pensamiento escolástico, «la costumbre era concebida como la expresión de la voluntad de la comunidad y, de tal forma, era equiparable a la ley» ${ }^{12}$. Así, según el Fuero Juzgo de Fernando III (ca. 1241), «la ley es por demostrar las cosas de Dios é que demuestra bien bevir... é que ordena las buenas costumbres, e govierna la cibdad $\gg^{13}$. La legitimidad de la costumbre como fuente de derecho (no escrito) procedía del uso, cuya principal característica consistía en la reiteración de una práctica social a lo largo de un extenso periodo de tiempo. En las Siete Partidas de Alfonso X (ca. 1252-1284) se establecía que el «uso es cosa que nasce de aquellas cosas que [el] hombre dice é face, é sigue continuamente por gran tiempo» y la «costumbre es derecho o fuero que non es escripto, el qual han usado los homes luengo tiempo» ${ }^{14}$.

Cabe recordar que el concepto de usos y costumbres fue utilizado para incorporar a las leyes de Castilla varias prácticas no-cristianas durante la «Reconquista» y la toma de las islas Canarias entre finales del siglo XV y principios del XVI. Tal fue el caso del llamado «derecho de aguas», versado en la cultura jurisprudencial del fiqh malequí andalusí, que contribuyó al mantenimiento de la agricultura hidráulica tanto en el Levante peninsular como en el archipiélago de las Afortunadas ${ }^{15}$. De la misma manera, varias modalidades de fiscalidad de raíz nazarí - como la renta de la Hagüela, el tegual o los habices - perduraron en el Reino de Granada tras la caída de su capital y se incorporaron a su legislación municipal mediante las famosas ordenanzas de $1552^{16}$. La añeja práctica del rescate monetario de cautivos árabes en los reinos infieles también fue apropiada por los príncipes cristianos, quienes regularon la existencia y competencias de los alfaqueques, agentes traductores encargados de esta rentable actividad ${ }^{17}$. El almotacenazgo, de tradición islámica, se convirtió igualmente en una institución crucial para la reglamentación de la vigilancia pública de pesos y medidas hasta el ocaso del Antiguo Régimen ${ }^{18}$. Así, en la Castilla tardo-medieval y moderna y sus posesiones, el concepto de usos y costumbres permitió la integración al orden

del Fuero Juzgo - se legitima la existencia de consuetudines y mores como fuentes de derecho. Véase Petit Calvo, 1984: 209-252. En torno a la recepción de la tradición jurídica bizantina en el México virreinal, véase Vargas Valencia, 2001.

12 Quijano, 2017: 27.

13 Fernando III, 1865, Título I, II Título de Leyes, Ley II: 15.

${ }_{14}$ Alfonso X, 1843, Partida Primera, Título II, Ley I y Ley IV: 15-16 y 18, respectivamente.

15 Macías Hernández, 2009: 724.

16 Vincent, 1985: 81-122. González Sopeña, 2017: 114-118.

17 García, 1987: 37-54.

18 Bejarano Galdino, 2000: 243-260. 
normativo - compuesto en su esencia misma - de prácticas procedentes de grupos socioculturales diversos.

Ahora bien, muchos de los funcionarios encargados de las primeras etapas gubernamentales de la Nueva España estaban familiarizados con esta cultura jurídica y con el diálogo asimétrico que se había establecido en la Península Ibérica con grupos no-cristianos. El presidente de la Segunda Audiencia (15301535), Sebastián Ramírez de Fuenleal, se formó en derecho canónico y civil en el Colegio Mayor de Santa Cruz de Valladolid, trabajó en el tribunal de la Santa Inquisición de Sevilla y fue oidor en la chancillería del Reino de Granada. Además, entre 1528 y 1530, fue obispo y presidente en la Audiencia de Santo Domingo, lo que le permitió experimentar las vicisitudes demográficas que padeció la población indígena antillana ${ }^{19}$. Por su parte, el oidor Alonso de Maldonado, letrado en derecho por la Universidad de Salamanca, fue alcalde mayor tanto de La Española como de Castilla del Oro del Reino de Tierra Firme, cargo que ocupó también, con atribuciones de juez de residencia, el oidor Juan de Salmerón ${ }^{20}$. El oidor Vasco de Quiroga no sólo había estudiado jurisprudencia en la Universidad de Salamanca, sino que frecuentó los círculos granadinos, fue juez de residencia en la plaza fuerte de Orán y participó en la firma del tratado de paz con el reino norafricano ziyánida de Tremecén ${ }^{21}$. Como muchos de los funcionarios peninsulares, el virrey Antonio de Mendoza (1535-1550) - bien relacionado con la burocracia castellana, así como con la real chancillería y el cabildo de Granada - recibió una educación, una formación y un entrenamiento cultural hispano-nazaríes ${ }^{22}$. En esta perspectiva, es legítimo preguntarse cómo, a raíz de la conquista y colonización de América, aquellos agentes usaron el concepto de usos y costumbres en el proceso de incorporación de los pueblos autóctonos al orden jurídico novohispano ${ }^{23}$.

\section{De LEYES (PREHISPÁNICAS) A COSTUMBRES (INDÍGENAS)}

En fechas tempranas, el término «costumbres» fue utilizado por los españoles para describir el orden normativo de los pueblos autóctonos previo a la

19 Sáez, 1996: 23, 24, 64-65. Otte, 1984: 241-265.

${ }^{20}$ Fernández de Navarrete, 1859: 471, 483. Argüello Solórzano y Molina Argüello, 2000: $125,193$.

${ }^{21}$ Warren, 1998: 14, 68, 123 y ss.

22 Jiménez Estrella, 2009: 211-232.

${ }^{23}$ Para analizar cómo los experimentos peninsulares en materia de gobierno de las poblaciones musulmanas fueron utilizados por los actores españoles en la gestión de la población indígena de América, veánse Graubart, 2015: 195-228 y Vallen, 2015: 77-98. 
conquista, realizando de este modo una operación de reducción conceptual. Esta interpretación aparece en un texto de fray Bernardino de Sahagún, en el que el religioso explicaba cómo, de 1524 en adelante, fue necesario

... destruir las cosas idolátricas, y aun las costumbres de la república que estavan mezcladas con rito de idolatría y acompañadas con ceremonias idolátricas, lo cual havia casi en todas las costumbres que tenia la república con que se regía, y por esta causa fue necesario desbaratarlo todo y ponerlos en otra manera de policía, que no tuviesse ningún resabio de cosas de idolatría ${ }^{24}$.

Como se intuye sin equívocos, la expresión «costumbres de la república» se refería a las leyes que habían regido las sociedades prehispánicas del centro de México antes de la conquista. El vínculo inextricable que éstas mantendrían con la «idolatría» justificó su destrucción y sustitución por «otra manera de policía», la policía cristiana ${ }^{25}$. Este mecanismo, que respondía al objetivo de someter a los pueblos autóctonos al orden legal colonial, era inverso al descrito en las ya aludidas Siete Partidas, donde se asentaban las condiciones para que la costumbre pudiese convertirse en fuente de derecho.

La voluntad de «desbaratarlo todo», para retomar los términos empleados por Sahagún, no debió de ser ajena al afán por destruir los registros escritos prehispánicos, ya que algunos documentos consignarían parte de la normativa vigente entre la población autóctona antes de la llegada de los españoles. Es, por lo menos, lo que sugiere este fragmento de la Información en derecho (1535), en la que el entonces oidor Vasco de Quiroga colegió:

Ordenanças no las tenían [los indios] sino unas pinturas a manera de annales que heran los casos y hechos como acontescian y passavan justa o injustamente y estos pintavan y los tenian no como leyes sino como exe'plos de lo que otros hazían mal o bien, que en derecho es Reprovado pues non exemplis sed legibus in [ju]dicandum est $t^{26}$.

${ }^{24}$ Sahagún, 2003, vol. II, libro X, cap. 27: 815-816.

${ }^{25}$ Es indudable que el programa evangelizador y el humanismo cristiano de raíz renacentista confluyeron en el tratamiento de los usos y costumbres en América. Nieto, 1976: 36-48. Malagón Pinzón, 2007: 131-147. Hanks, 2010: 1-3. Owensby, 2011: 61, 64-75. Por ejemplo, el erasmismo permeó el programa pedagógico del célebre Colegio Imperial de Santa Cruz de Tlatelolco (Pollnitz, 2017: 126, 129, 132 y ss.). Asimismo, los tópicos del clasicismo y del providencialismo influyeron en las obras de varios cronistas de tradición indígena (Laird, 2018: 86-103). Y ciertos personajes bíblicos o la materia escatológica fueron, de igual modo, objeto de atención hermenéutica. Véase en Olko, 2017: 150-151, 159-166. Leeming, 2017: 174-178. Agradecemos al evaluador anónimo la indicación de estos importantes aspectos.

${ }^{26}$ Información en derecho, 1535, Ciudad de México, Biblioteca Nacional de España, Madrid (BNE), ms. 7369, f. 81r. Quiroga sigue aquí, en su inserto en latín, el Código de Justiniano $(\mathrm{C} .7,45,13)$, por el cual «no se puede juzgar por los ejemplos o hechos particu- 
Pero, si bien Quiroga reconocía la existencia de registros escritos enfocados en la administración de la justicia, negaba que aquellos documentos tuvieran pleno valor legal ${ }^{27}$. De hecho, el oidor añadió que las poblaciones indígenas de la altiplanicie de México fueron «gentes sin ley ni justiçia ordenada, de manera que cada uno se salia con lo que quería ${ }^{28}$.

Un fenómeno similar ocurrió en Yucatán a partir de 1545. Aunque los franciscanos pronto reconocieron la eficacia del sistema escriturario maya, al aseverar que los indígenas usaban «de ciertos caracteres o letras con las cuales escribían en sus libros sus cosas antiguas y sus ciencias», establecieron un vínculo entre los códices prehispánicos y la idolatría. De este modo, en su Relación de las cosas de Yucatán fray Diego de Landa explicó cómo se empezaron a buscar y hallar un "gran número de libros de estas sus letras y, porque no tenían cosa en que no hubiese superstición y falsedades del demonio, se los quemamos todos, lo cual [los indios] sintieron a maravilla y les dio mucha pena» ${ }^{29}$. Así, aunque en la historiografía se suele relacionar la destrucción sistemática de los registros prehispánicos con la voluntad de borrar la memoria de las antiguas creencias autóctonas para imponer la religión cristiana, es posible que tal aniquilamiento documental también tuviera que ver con el deseo de erradicar los soportes materiales en los que se contenía el antiguo orden normativo, a fin de irlo sustituyendo progresivamente por otro ${ }^{30}$.

lares precedentes, sino de acuerdo con la ley». La Información en derecho de Vasco de Quiroga fue publicada originalmente en el CODOIN (1868, tomo XI: 333-524). Los autores del presente estudio utilizan la fuente archivística original, a fin de incorporar los marginalia y las anotaciones intertextuales al análisis del documento.

${ }^{27}$ Los íconos recogidos en tales «pinturas», «libros » o «anales que eran de los casos y hechos» no serían sólo pictografías mnemotécnico-pedagógicas, sino más bien sistemas escriturarios en los que se almacenaría una praxis judicial empírica en base a las sentencias dictadas. Véase en Lacadena, 2008: 1-22.

${ }^{28}$ BNE, ms. 7369 , f. $77 \mathrm{v}$.

${ }^{29}$ Landa, 2019: 80.

30 En realidad, ambos procesos eran altamente complementarios. Cabe matizar, sin embargo, que para el México central está certificada la conservación interesada de un reducido número de fuentes pictográficas prehispánicas de naturaleza legal, al menos durante el siglo XVI y tal vez allende. Tal parece haber sido el caso de los repositorios documentales sobre tributos y pleitos que estaban bajo el control de la parentela de Hernando de Tapia, nahuatlato de la Real Audiencia. Véase en La muger y herederos de Hernando de Tapia con el barrio de San Juan por casas en San Pablo, 1576, Ciudad de México, Archivo General de la Nación de México, México D. F. (AGN), Tierras, vol. 37, exp. 2. En Texcoco, la familia caciquil local poseía códices antiguos en los que se contenían, entre otros asuntos de índole jurídica, las célebres ochenta leyes del antiguo huey tlahtoani Nezahualcoyotl, las mismas que el cronista Fernando de Alva Ixtlilxóchitl - y también Nahuatlato- consultó y referenció. Véase en Ixtlilxóchitl, 2000, cap. XXXVIII: 156-161. Brian, 2016. 
A este propósito, resultan de sumo interés las observaciones que fray Andrés de Olmos realizó acerca del concepto de tlamanitiliztli, voz nahua que en el México de la post-conquista llegó a designar ciertos códigos morales, conductas éticas y preceptos normativos nahuas ${ }^{31}$. En algunos de sus huehuetlatolli confesionales de la década de 1540 —incorporados más tarde a la Historia general de las cosas de la Nueva España y al Códice Florentino de fray Bernardino de Sahagún-, el religioso asentó que tlamanitiliztli era lo que «dexaron escripto o pintado o por memoria los antiguos [indígenas]» y «las leyes y costumbres que dexaron los antiguos en la república $»^{32}$. Si bien en esta cita todavía aparecía la idea de código legal (escrito con sistemas escriturales prehispánicos), poco a poco se operó un deslizamiento hacia el sentido de usos y costumbres, por un lado, y de leyes coloniales recogidas alfabéticamente, por otro. En su Vocabulario en lengua mexicana y castellana, fray Alonso de Molina indexó la voz tlamanitiliztli como «uso o costumbre de pueblo, o ordenanças que en el se guardan $\rangle^{33}$. Un proceso similar se observa en el Calepino de Motul, uno de los primeros vocabularios de la lengua maya yucateca, que define por igual la voz tzolaan be como «orden y modo de vida» $\mathrm{y}$ ofrece a modo de ejemplo la expresión «u tzolaan bee halan tumen halach uinic, ordenanzas del gobernador ${ }^{34}$.

Sin llegar a orillar la probable matriz cultural mesoamericana que destilaban los conceptos de tlamanitiliztli y tzolaan be, no deja de sorprender la afinidad semántica existente entre ambos vocablos, según lo expresado por

31 Sobre este concepto véanse León-Portilla, 2006: 234-236 y 391. Zantwijk, 1959: 123. Flores García, 2007: 4.

32 «Intlil, intlapal in vevetque», citado por Sahagún, 2003, vol. I, libro VI, cap. 43: 610. En otro huehuetlatolli, la voz tlamanitiliztli fue definida como todo aquello por lo que los indígenas nahuas «se han de entregar a lo conveniente y recto, [y] han de evitar lo malo». Véase en «Huehuetlatolli, Documento A», citado por León-Portilla, 2006: 233 y 234.

${ }^{33}$ Molina, 1571: f. 125v. Tlamanitiliztli formaba parte del campo semántico de otros conceptos análogos, como toltecayotl $-\mathrm{u}$ «oficio o arte para vivir» (Ibidem: f. 90r.) - o tlatlaliliztli / tlatecpanaliztli / nauatilli, la «regla de vivir» (Ibidem: f. 103r). De hecho, en los Códices Matritenses de fray Bernardino de Sahagún (1558-1569) se habla igualmente de la «Tollan tlamanitiliztli», es decir, la «costumbre y orden [que se] vsava... en el pueblo de tulla». Véase en Dibble, 1999: 37. Es más: tlaminitiliztli proviene de la raíz verbal mani, traducida por Frances E. Karttunen, en su forma pretérita (manca), como «something flat to cover a surface, as water in a shallow pan / estar cosas llanas» (Karttunen, 1992: 136). Así, se entiende la entrada que figura en Molina 1571: f. 52r (mani topam, «los que nos rigen y goviernan» $[$ mani $=$ extender $]+[$ to $=$ nosotros + pan $=$ sobre, encima $])$. Expresamos nuestra gratitud al evaluador anónimo por habernos llamado la atención sobre este último aspecto.

${ }^{34}$ Arzápalo Marín, 1995, vol. 1: 199. Sobre el sentido que atribuyeron los diccionarios coloniales a la voz maya tzol-, véase Hanks, 2010: 183-185. 
las narrativas franciscanas. No podemos olvidar que la provincia seráfica del Santo Evangelio de México abarcó la custodia de San José de Yucatán hasta 1565, fecha muy próxima a la institucionalización de la nueva diócesis regional (1562) bajo la mitra de fray Francisco de Toral, también franciscano. Así, el desplazamiento de ministros, guardianes, definidores y custodios seráficos desde las tierras altas hacia Yucatán fue constante en las primeras décadas que siguieron a la conquista ${ }^{35}$, transportando experiencias etnográficas, bagajes intelectuales, expectativas, esquemas cívico-pastorales y literaturas eclesiásticas de uno a otro espacio ${ }^{36}$. Prueba de todo ello es la trayectoria personal del primer ordinario yucateco, que, antes de su traslado a Mérida, había sido ya comisario general, padre provincial del Santo Evangelio y guardián del convento de Tecamachalco, donde, aparte de estar familiarizado con el idioma náhuatl, había estudiado y reducido la lengua local popoloca ${ }^{37}$. Un caso similar fue el de fray Miguel Navarro, quien llegó a Nueva España en 1535, fue igualmente guardián en Tecamachalco para $1551 \mathrm{y}$, a inicios de la década de 1560, mantuvo algún tipo de relación con la custodia y el obispado de Yucatán $^{38}$. Resulta bastante evidente, pues, que los frailes doctrineros contribuyeron a homogeneizar una nueva percepción de la existencia indígena.

En las definiciones de tlamanitiliztli y tzolaan be recogidas en los mencionados diccionarios coloniales se estaba actualizando, por tanto, la adecuación del pensamiento autóctono al proyecto evangelizador y político hispano ${ }^{39}$. Según James Lockhart, esto condujo a la sustanciación del fenómeno que definió como

${ }^{35}$ Frailes que fueron enviados tempranamente a Yucatán desde el altiplano de México y también a Guatemala fueron Jacobo de Testera, Luis de Villalpando, Lorenzo de Bienvenida, Melchior de Benavente o Juan de Herrera. Véase en Torquemada, 1973-1985, vol. VI, libro XIX, cap. XIII: 54-57.

${ }^{36}$ Acerca de los estudios comparativos a estos respectos, véase, por ejemplo, Christensen, 2013; 2014.

37 Torquemada, 1973-1985, vol. VI, libro XX, cap. LXXI: 359. Celestino y Reyes García, 1992: 39-40.

${ }^{38}$ Fray Alonso de Castillejo, Fray Miguel Navarro y Fray Martín de Villegas, franciscanos de la provincia de Murcia, a Nueva España, Pasaje a Indias, Sevilla, 2 de abril de 1535, AGI, Contratación, 5536, 1. 3: f. 166r. A los oficiales de la Casa de la Contratación para que permitan a Fray Miguel Navarro llevar a la provincia de Yucatán 6 labradores casados, con sus mujeres e hijos, Real Cédula, Daimiel, 1 de enero de 1563, AGI, Indiferente General, 1966, 1. 14: f. 308v. Celestino y Reyes García, 1992: 78. Años más tarde, Navarro lograría convertirse en definidor / procurador de la orden, provincial del Santo Evangelio de México, custodio y comisario general de los franciscanos novohispanos.

39 El aparato ontológico, epistémico y hermenéutico que los agentes españoles emplearon para acercarse a la realidad nativa mediante procesos de re-significación, re-semantización y reconfiguración semiológica se discute en Lockhart, 1992: 445-446. Hanks, 2010: 4-7. 
«doble identidad mal-interpretada», es decir, la reapropiación recíproca entre españoles e indígenas de elementos culturales de ambas alteridades, sin llegar a interesarse por profundizar en una comprensión cabal sobre éstas ${ }^{40}$. Es cierto que las fuentes en náhuatl del siglo XVI hicieron un uso intensivo de la noción de tlamanitiliztli. Por poner algunos ejemplos, se pueden mencionar los denominados Coloquios de 1524 - compilados en la década de 1560 - en los que los informantes indígenas de Sahagún trajeron a colación la vueve tlamanjtiliztlj, que el editor contemporáneo de esta versión tradujo como «antigua regla de vida»" En una miscelánea de fuentes sobre tierras ubicadas en la localidad de Cuauhtinchan, se relató acerca de una serie de procedimientos que «ello no está de acuerdo con el antiguo orden», según la interpretación al castellano que el compilador ofreció («au inin ca aocmo quinamiqui yn ye uecauh tlamanitiliztli») $)^{42}$. Por último, en la Crónica mexicáyotl — cuya presunta autoría no se asociaría a Hernando de Alvarado Tezozómoc ${ }^{43}$ — se dio cuenta de la existencia de «ynin yeliz $y$ nin tlamanitiliz», «la vida de ellos, los usos de ellos [los antiguos] $»^{44}$.

En resumidas cuentas, la reducción conceptual de las «leyes» prehispánicas al estatuto de «costumbres» indígenas, así como la vinculación de las mismas con la esfera de lo idolátrico, justificaron el intento de destrucción de las antiguas normas (ya fueran escritas o tácitamente reconocidas). Estos procesos se llevaron a cabo de forma paralela a la re-significación de algunas voces autóctonas, destinadas a hacer desaparecer su asociación con el orden sociocultural prehispánico y sustituirlo por nuevos referentes. No obstante, el empleo colonial del concepto de costumbres resultó aún más complejo, puesto que también abarcó una vertiente de posible reconocimiento legal — para usar un término contemporáneo- de algunas prácticas indígenas. En efecto, las leyes indianas contemplaron la posibilidad de otorgar plena validez legal a las «buenas costumbres» indígenas.

DE «BUENOS USOS Y COSTUMBRES» INDÍGENAS A LA LEGALIDAD COLONIAL

Una de las primeras cédulas en la que la Corona ordenó que a los naturales «se [les] guarde[n] sus buenos vsos y costumbres en lo q' no fuere' co'tra

40 Lockhart, 1999: 98-119.

41 Sahagún et al., 1986: 150-153.

42 Reyes García, 1978: 198.

${ }^{43}$ En los últimos años, se ha empezado a revaluar la autoría de esta obra. Algunos estudios apuntan al indígena Domingo Francisco de San Antón Muñón Chimalpahin Quauhtlehuanitzin como probable redactor o compilador. Véase en Schroeder, 2011.

44 Tezozómoc, 1998: 13. La edición de Adrián León —que los autores seguimos en este artículo - cita la fuente en náhuatl de ese modo. La fórmula corregida sería «yn inyeliz yn intlamanitiliz». 
nuestra religion christiana» fue despachada en $1530^{45}$. En una provisión de 1550 se dispuso, asimismo, que los pleitos entre indios o con ellos fuesen determinados «sumariamente... guardando sus usos y costumbres no siendo claramente injustos $»^{46}$. En 1555 el rey y su Consejo reiteraron:

... aprobamos y tenemos por buenas vuestras buenas leyes y buenas costumbres que antiguamente entre vosotros habéis tenido y tenéis para vuestro buen regimiento y policía y las que habéis hecho y ordenado de nuevo todos vosotros juntos con tanto que nos podamos añadir lo que fuéremos servido y nos pareciere que conviene al servicio de Dios nuestro señor y Nuestro y a vuestra conservación y policía cristiana, no perjudicando a lo que vosotros tenéis hecho ni a las buenas costumbres y estatutos vuestros que fueren justos y buenos ${ }^{47}$.

Más allá de las limitaciones que contenían estas disposiciones, que analizaremos en adelante, es preciso interrogarse sobre los motivos que empujaron la Corona a tomar esta decisión. En realidad, estas medidas no debieron de ser ajenas a la lucha de intelectuales como fray Alonso de la Veracruz o fray Bartolomé de las Casas, entre otros importantes agentes eclesiásticos, para que fuera reconocido el autogobierno indígena, cuando menos a nivel de los cabildos de los «pueblos de indios» y de la obtención privativa del estatus jurídico de «ciudad» en algunos de ellos, como Tlaxcala ${ }^{48}$. En esta perspectiva, estos autores, que pertenecían a la corriente conocida como Escuela de Salamanca o Segunda escolástica — basada en el iusnaturalismo neotomista-, no dudaron en utilizar teorías «constitucionalistas» según las cuales «la autoridad estaba limitada por una serie de normas, costumbres o principios fundamentales, anteriores e independientes del gobernante» ${ }^{49}$. Así pues, para Las Casas, el gobernante tenía que respetar no sólo el derecho natural, sino también la voluntad del pueblo que se expresaba tanto en diversos pactos como en los usos y costumbres de la comunidad ${ }^{50}$. En su tratado De thesauris, el dominico insistía en que el rey prometería al pueblo que

45 Puga, 2012: f. 54r.

46 "Provisión que manda particularmente la orden que las Audiencias y otras justicias de las Indias han de guardar y fulminar los pleitos de indios y en su determinación (1550)", citado por Encinas, 1945, libro II: ff. 166-167.

47 "Cédula en que se aprueba a los indios las buenas costumbres que antiguamente han tenido y tienen para su buen regimiento y policía (1555)", citado por Encinas, 1945, libro IV: ff. 355-356. También, en Recopilación de las Leyes..., 1681, Libro Segundo, Título Primero, Ley IV, carácter general.

48 Véanse Velasco Gómez, 2008. Quijano, 2017. Rovira Morgado y Fracas, 2018.

49 Quijano, 2015: 10.

50 Ibidem: 32-33. 
... introducirá un buen régimen, que concederá libertad y exenciones, que favorecerá las buenas costumbres que se mantienen por tradición desde la antigüedad o, si éstas no existen, o al pueblo ya no le agradan las viejas costumbres, que favorecerá otras nuevas y otros privilegios favorables que el pueblo pida para sí, para su conservación, en el marco de un perfecto estado de toda la república ${ }^{51}$.

No cabe duda de que, para Las Casas, aquellos preceptos también tenían que aplicarse a los territorios ultramarinos para que la soberanía de los reyes de Castilla sobre los pueblos autóctonos pudiese ser considerada como legítima. Es probable, por lo tanto, que las cédulas relativas a los usos y costumbres indígenas hundieran sus raíces en la defensa del gobierno autóctono, orquestada por intelectuales como Veracruz o Las Casas, principalmente. De hecho, resulta llamativa la interpretación que las mencionadas disposiciones hicieron del término «costumbres», que, al igual que en el tratado lascasiano, no sólo se refería a las prácticas prehispánicas que seguían vigentes en el periodo colonial (las «costumbres que antiguamente entre vosotros habéis tenido y tenéis»), sino también a las que habían surgido después de la conquista («las que habéis hecho y ordenado de nuevo todos vosotros juntos»)). De este modo, el criterio de antigüedad era, hasta cierto punto, relativo y había de combinarse con lo aceptado colectivamente por la comunidad («todos vosotros juntos»).

Sin embargo, no es menos cierto que la expresión «aprobamos y tenemos por buenas vuestras buenas leyes y buenas costumbres» entrañaba la idea de una selección de las costumbres indígenas, realizada por parte de una entidad externa y superior. En otras palabras, las costumbres indígenas se situaban en una zona intermedia, ubicada a medio camino entre el uso y el derecho. En efecto, para que un uso alcanzara el estatuto de costumbre se apelaba a su antigüedad y/o a su aceptación dentro de una comunidad. Pero, a su vez, para que una costumbre pudiese convertirse en fuente de derecho, debía ser conforme al «servicio de Dios nuestro señor y Nuestro y a vuestra conservación y policía cristiana». Aquellas cédulas establecían, por ende, una jerarquía entre el derecho consuetudinario (indígena), por un lado, y el derecho común (indiano) y el derecho natural, por otro. Es interesante observar que Sebastián de Covarrubias también insistiría en esta jerarquía en su Tesoro de la lengua castellana (1611) cuando, al citar el refrán «la costumbre hace ley», lo interpretó de la siguiente manera: «entiéndese cuando no hay ley en contrario ni repugna a la razón y justicia» ${ }^{52}$. Así pues, vemos cómo, tanto en América como en la Península Ibérica, se estaban materializando las tensiones entre potestas —el poder emisor y velador de una normatividad - y auctoritas

${ }^{51}$ Casas, 1992: 307-309, citado por Quijano, 2015: 33.

52 Covarrubias, 1995: 363. 
— dominio receptor no vinculante, aunque validado y admitido socialmentecaracterísticas comunes en las sociedades de Antiguo Régimen ${ }^{53}$.

Otro punto álgido tuvo que ver con los ámbitos jurisdiccionales en los que se podía apelar a la costumbre como fuente de derecho. La costumbre tenía validez legal dentro del pueblo de indios y, en este caso, les correspondían a los gobernadores y los cabildos indígenas evaluar su antigüedad y/o común aceptación por la comunidad, así como su conformidad con la policía cristiana y las leyes indianas. Pero los indígenas - aunque no fueron los únicos- también podían recurrir al razonamiento de la costumbre ante los demás tribunales novohispanos, $\mathrm{y}$, en este caso, eran los jueces quienes determinaban la fuerza legal de la costumbre invocada a la hora de sentenciar las causas. Ello nos conduce a realizar dos observaciones, que permiten esclarecer el tratamiento de la costumbre tal como fue dispuesto en América durante el periodo colonial. En primer lugar, el concepto se caracterizó por un alto grado de flexibilidad, ya que podía incluir casi cualquier práctica sociocultural indígena, ya fuera de origen prehispánico o no, siempre que gozara de una relativa antigüedad y/o de una relativa aceptación colectiva. En segundo lugar, se otorgó a los jueces un amplio margen de maniobra (y, por lo tanto, de poder) a la hora de dar (in)validez legal a una costumbre indígena. De hecho, resulta significativo observar cómo las ambigüedades en torno a las costumbres se materializaron en el registro escrito.

\section{LAS COSTUMBRES EN EL REGISTRO ESCRITO, ENTRE OMISIÓN Y RECUPERACIÓN}

Si bien la Corona otorgó cierto margen para reconocer las «buenas costumbres» indígenas, éstas no llegaron a permear la codificación escrita conformada por el corpus de ordenanzas para pueblos de indios, lo que contribuyó a reforzar la condición de incertidumbre, indefinición y hasta incoherencia que rodeó aquellas prácticas. Ya se ha dicho que, en las primeras décadas del periodo virreinal, los españoles orquestaron una campaña de destrucción sistemática de los documentos prehispánicos, inclusive algunos que podrían haber llegado a contener informaciones relacionadas con la administración de justicia de tradición mesoamericana. Es lógico, por tanto, que este tipo de documentos no integrase el orden normativo escrito que circulaba por los pueblos de indios, que, en aquel entonces, estaban más bien 'saturados' por traducciones a las lenguas autóctonas de «Ordenanzas para el buen gobierno», redactadas por virreyes u oidores desde la década de los 1530 en el altiplano de México y de los 1550 en la península yucateca.

${ }^{53}$ Domingo, 1997: 183 y ss. Estruch, 2012: 78-102. Daston y Stolleis, 2016: 35, 49, 79, 85. 
Ya en 1536, Isabel de Portugal y el Consejo de Indias remitieron una real cédula y minuta anexada a las autoridades de la Audiencia mexicana, en las que se les conminaba a que se hiciera un

... memorial de las cosas que os parece de q.e los Yndios naturales desa tierra deven ser avisados, e apercividos, q.e guarden, è cumplan y a lo que deven apartarse assi en las idolatrias, y sacrificios que suelen hacer, como en los otros malos rritos, vicios y costumbres reprobadas, q. suelen tener, assi fuera de la razón y ley natural como contra d[e]r[ech]o Divino, y humano, y leyes de nuestros Reynos ${ }^{54}$.

Con toda probabilidad, la junta eclesiástica que tuvo lugar en la ciudad de México a finales de 1536 fue el escenario en que autoridades civiles y religiosas dieron curso a la ulterior codificación de tales ordenanzas ${ }^{55}$. Hasta donde tenemos conocimiento, la versión príncipe de estos reglamentos generales decretados cabría situarla hacia 1537, y se mantendría inédita. Sólo la conocemos por dos trasuntos: las ordenanzas indexadas en las instrucciones tituladas Las cosas que se han de yndustriar y amonestar a los naturales de [Nueva] Galizia (ca. 1537) ${ }^{56}$, así como un Traslado de ciertas ordenanzas fechas por el Abdiencia Real insertas en una provisión sellada con el sello real (1539) ${ }^{57}$. En lo subsiguiente, ciertos aspectos de las Leyes Nuevas o de las instrucciones del visitador general Francisco Tello de Sandoval para la Audiencia de México (1544) parecerían contener información análoga ${ }^{58}$. Cabe pensar que todo ello debió influir en la promulgación final de las Ordenanzas para el gobierno de indios de Antonio de Mendoza (1546), que fueron objeto de transcripción al náhuatl poco tiempo después ${ }^{59}$. Estos textos se convirtieron en un auténtico arquetipo para la elaboración de diversas ordenanzas, tanto en las tierras altas del centro de México como en otras partes del virreinato ${ }^{60}$.

54 "Real cédula y minuta de la Corona y del Consejo de Indias a la Real Audiencia de la Nueva España. Madrid, 11 de marzo de 1536”, citado por Cedulario Índico de..., 1773-1793, vol. IX, registro n. ${ }^{\circ}$ 114. También en Archivo Histórico Nacional de España, Madrid (AHN), Códices, 1. 692, vol. IX: ff. 81r-83r. Sólo cuatro meses más tarde, la Corona giró unas nuevas instrucciones al virrey Mendoza, insistiéndole en cuestiones similares. Instrucciones a Antonio de Mendoza, Madrid, 11 de julio de 1536, AGI, Indiferente General, 415, 1. 2, f. 360r.

55 Gil, 1989: 7-34.

56 Puga, 2012: ff. 158v-159v.

57 Carreño, 1944: 130-135.

${ }^{58}$ Francisco Tello de Sandoval, Ordenanzas de la Audiencia de México (1544), BNE, ms. 2951, ff. $1 \mathrm{r}-48 \mathrm{v}$.

59 O’Gorman, 1940: 179-194. Ordenanças de su mag.t, Bancroft Library-University of California, citado por Sell y Kellogg, 1997: 325-367.

${ }^{60}$ Sobre la difusión de aquellos modelos en el altiplano de México, véase Rovira Morgado, 2017: 75-104. Olko y Brylak, 2018: 574-575. Para Yucatán, véase Cunill, 2015: 15-36. 
Ahora bien, la relación que aquellos textos normativos mantuvieron con los usos y costumbres indígenas se caracterizó por su alto grado de ambigüedad. Así, por ejemplo, en las Ordenanzas para pueblos de indios de Yucatán (1583), el oidor Diego García de Palacio enumeró la larga lista de obligaciones que contraían los gobernadores y cabildantes mayas ${ }^{61}$. No obstante, no explicitó los mecanismos que habían de seguirse para escoger a los cargos de república, limitándose a estipular que «en la elección del gobernador se guarde lo que hasta aquí [se ha usado]» ${ }^{62}$. Más adelante, el oidor reiteró, sin entrar en más detalles, que «los dichos gobernador, alcaldes y regidores [...] tratarán y comunicarán sobre elegir y nombrar por alcaldes, regidores y alguaciles y otros oficios de su cabildo por aquel año» ${ }^{63}$. Sólo dispuso que se habría de privilegiar para estos cargos a «los indios de más entendimiento, buenos cristianos y cuidadosos del beneficio de sus milpas y gobierno de sus mujeres e hijos y tales que se espere que miraran por el bien y provecho universal de aquel pueblo ${ }^{64}$. Por si quedara alguna duda acerca del carácter voluntario del mantenimiento de un importante nivel de imprecisión en el registro de las normatividades autóctonas por parte de las autoridades coloniales, uno puede remitirse a las glosas que agregó el mismo oidor a la copia de las Ordenanzas y que entregó al Consejo de Indias para su confirmación. En el margen de este documento se puede leer, en efecto, «pónese algo groseramente la forma de elegir porque no son capaces estos indios para más» ${ }^{65}$.

No cabe duda de que la imposición de la policía cristiana - exigida a través de la evangelización, la reducción de los pueblos de indios y la implementación de los cabildos de estilo hispano-- asestó un duro golpe a lo que hubiera sido el antiguo orden normativo de los pueblos autóctonos. Cobra aquí especial relevancia lo razonado por un principal octogenario de México, quien habría declarado al oidor Alonso de Zorita que «nos habéis quitado nuestra buena orden y manera de gobierno y la que habéis puesto no la entendemos, y así anda todo confuso y sin orden y concierto» ${ }^{66}$. Por su parte, en 1582 , el maya Gaspar Antonio Xiu, encargado por el gobernador don Guillén de las

${ }^{61}$ García Bernal, 1985: 1-12.

62 Ibidem: 8.

${ }^{63}$ Idem.

${ }^{64}$ Idem.

${ }^{65}$ Idem.

${ }^{66}$ Zorita, 1993: 51-52. Y es que conviene no olvidar que el tránsito itinerante de especialistas de la justicia pública a lo largo y ancho del territorio novohispano contribuyó a la difusión y estandarización de esta cultura normativa. Baste recordar el caso del oidor Alonso de Maldonado, quien, tras haber desarrollado una larga experiencia en la Audiencia de México (1531-1542), se convirtió en el presidente de la nueva Audiencia de Guatemala. 
Casas de redactar un informe de las antiguas costumbres indígenas, realizó un balance similar. Al final de su «Relación de algunas costumbres», el entonces intérprete del juzgado del gobernador de Yucatán, afirmó que:

[Estas y otr] as muchas costumbres tenian los indios destas [provincias] de yucatan de las quales se an perdido muchas [y no] tienen al dia de oy, las cuales yo Gaspar Antonio [na]tural desstas provincias... recopile por mandado del muy ilustre senor don guillen de las casas gobernador y capitan general ${ }^{67}$.

En realidad, llama la atención la aparente paradoja que entrañaba aquel afán por conservar un registro escrito de las antiguas leyes indígenas en el preciso momento en el que éstas, como bien notara Gaspar Antonio, habían en gran parte desaparecido. Hay que recordar, en efecto, que la «Relación de algunas costumbres» de Gaspar Antonio respondía a uno de los múltiples aspectos que la Corona española mandó investigar a través de los famosos cuestionarios de 1573 y su actualización de 1577. En el cuestionario de 1573, la pregunta 18 ordenaba averiguar «todo lo que [los naturales] tuvieren en su infidelidad y lo que de ello se les debería quitar y lo que de ello se les debería conservar, las cosas de que se han hecho novedades después que en ellas entraron españoles» ${ }^{68}$. En 1577 también se pidió información sobre «cuyos eran [los pueblos de indios] en tiempo de su gentilidad y el señorío que sobre ellos tenían sus señores, y lo que tributaban y las adoraciones y costumbres buenas y malas que tenían» y sobre «cómo se gobernaban y con quién traían guerra y cómo peleaban y el hábito y traje que traían y el que ahora traen. Y los mantenimientos de que usaban y ahora usan y si han vivido más o menos sanos antiguamente que ahora, y la causa que de ello se entendiere ${ }^{69}$. También es preciso señalar la cédula de 1580 en la que el Consejo de Indias pidió a los oidores y presidentes de las Reales Audiencias americanas que enviasen «una información completa de las usos y costumbres que en materia de justicia tenían los indios antes de la conquista española, pues por ellos deben regirse $\rangle^{70}$.

${ }^{67}$ Strecker y Artiega, 1978: 17.

${ }^{68}$ Solano, 1988: 23.

${ }^{69}$ Ibidem: 82.

${ }^{70}$ Real cédula a Martín Enríquez, virrey del Perú, mandándole que envíe al Consejo de Indias una información completa de las usos y costumbres que en materia de justicia tenían los indios antes de la conquista española, pues por ellos deben regirse, Badajoz, 23 de septiembre de 1580, AGI, Indiferente General 427, 1. 30: ff. 323r.-324r. Una anotación marginal señala que «se despacharon otras tales cédulas para las demás Audiencias y gobernadores de las Indias». La cédula fue publicada por Konetzke, 1953, vol. 1: 529-530. Encinas también recopila un documento de esta índole, pero sin precisar su fecha. "Capítulo de la instrucción 
Así, tanto en Yucatán como en otras partes de América, se puso en marcha un proceso de recolección de antiguas tradiciones indígenas. Efectivamente, en las tierras altas de México, en 1582, se documentan los Romances de los señores de la Nueva España, incluidos en la Relación geográfica de Texcoco. Por las mismas fechas, se procedía también a efectuar la compilación final de los denominados Cantares mexicanos. Aunque poco conectados en su motivación con esta miscelánea, en torno a 1582, se reunieron los Anales de Juan Bautista a partir de varios textos y personalidades implicadas ${ }^{71}$, fuente que constituye también una verdadera ventana documental a las prácticas administrativas, legales y culturales de los indígenas tenochcas durante la segunda mitad del siglo XVI. Y, por otra parte, en 1583, fray Bernardino de Sahagún sacaba a la luz su Psalmodia Christiana, obra particular mediante la cual se ensalzaba la conversión al cristianismo de los nahuas atendiendo a sus cantos y bailes tradicionales ${ }^{72}$. Este fenómeno de recopilación de la antigua normatividad indígena recuerda, en cierto modo, la compilación de antiguos pergaminos y documentos legales locales que se realizó en la Europa central de finales del siglo XV en nombre de la preservación de las «costumbres» ${ }^{73}$. Según Simon Teuscher, «la costumbre se convirtió en un argumento de legitimación de prácticas consistentes en recolectar normas y en extraer diversos materiales de su contexto con el fin de movilizarlo y de adecuarlo a un amplio abanico de propósitos» ${ }^{74}$. El contenido de los cuestionarios también sugiere que el interés de la Corona por conocer las prácticas autóctonas (ya fueran

que se da a los virreyes del Perú que manda se informe de la manera de gobernación que tienen entre sí los indios y envíe relación”, Encinas, 1945, libro IV: 356-357.

71 Reyes García, 2001: 27-28.

72 Vale la pena mencionar que el espíritu de todos estos cuestionarios y registros fue muy cercano en el tiempo a la publicación oficial de las famosas Ordenanzas del Bosque de Segovia (13 de julio de 1573), a través de las cuales Felipe II implementó reformas tendientes a la «pacificación de las Indias». Pero también, a la Ordenanza de Patronato Regio (1 de junio de 1574) y a la real cédula de secularización integral de doctrinas americanas (1583). En todas ellas, se legitimaba el fortalecimiento de la jurisdicción regia y la afirmación de la Iglesia secular, que reprochaba sin tapujos la indigenización del catolicismo que las órdenes regulares habían fomentado hasta entonces al permitir la inclusión de una elevada amalgama de usos y costumbres nativos en la liturgia cristiana. Como es sabido, estos asuntos condicionaron la agenda del III Concilio Provincial Mexicano (1585). Veáse Ordenanzas de descubrimiento, nueva población y pacificación de las Indias, Provisión Real, Felipe II, 13 de julio de 1573, AGI, Indiferente General, 427, 1.29: ff. 67r-93v. Encinas, 1945, libro I: 83-86. A los prelados del conçilio que se celebrase en mex.co sobre la Resoluçion q' se ha tomado en lo de las doctrinas, Ordenanza, Felipe II, Madrid, 6 de diciembre de 1583, AGI, Indiferente General, 427, 1. 30: ff. 364r-366r.

73 Teuscher, 2010: 211-229.

${ }^{74}$ Ibidem: 225. Traducción de los autores. 
prehispánicas o contemporáneas) no tenía tanto que ver con su salvaguardia, que con su selección y la voluntad de que el nuevo orden político $-\mathrm{y}$, de paso, el mismo rey- fuese percibido como más justo que el antiguo sistema (y sus representantes) por las poblaciones indígenas ${ }^{75}$.

\section{LOS USOS Y COSTUMBRES EN LA PRÁCTICA JUDICIAL NOVOHISPANA}

Este último punto nos conduce a enfatizar que, a fin de cuentas, las costumbres autóctonas únicamente alcanzaron el universo escrito a través de los pleitos, llegando, como mucho, a la movediza esfera de la jurisprudencia. Pero, por su misma plasticidad, la costumbre se convirtió en un formidable instrumento de negociación para los pueblos indígenas, que no dudaron en recurrir a este argumento en los tribunales ${ }^{76}$. Así, la capacidad de apropiación del concepto por los actores, ya fueran españoles o indígenas, litigantes o procuradores, dio lugar a un extenso abanico de usos del mismo en la práctica judicial. Por ejemplo, el interés que la Corona mostró por sacarle el máximo provecho al sistema fiscal indígena fue un catalizador para la mención oportunista de los usos y costumbres. Según el arzobispo Alonso de Montúfar, el tributo tenía que ser recaudado por los oficiales españoles, porque «si se dejase a los indios cobrar su mitad, los colectores robarían a los pobres [maceguales] y cobrarían más que doblado, como es costumbre entre ellos» $\rangle^{77}$. Sin embargo, en un memorial despachado por los franciscanos, se aducía que «pareçe también el excesso de la dicha [nueva] tassa y el perjuicio q' della se sigue a los yndios, porq' en la cuenta q' se haze de los tributarios incluyen los caçiques y prinçipales y a otros generos de personas q' conforme a todo derecho habian de ser rreservados ${ }^{78}$.

Los mismos indígenas recurrieron al concepto de forma ambivalente, ya que no dudaron en jugar con las categorías de «malas» y «buenas» costumbres para defender sus intereses en los tribunales. Un ejemplo muy prematuro de ello lo encontramos en el conocido juicio de la inquisición apostólica contra el cacique tetzcocano don Carlos Ometochtzin Chichimecatecuhtli, en 1539, momento en que las modalidades de protectoría jurídica civil hacia los natu-

75 Cunill, 2020: 47-68.

76 Yannakakis, 2010: 137-173. Premo, 2014: 355-379.

77 Parecer del Arzobispo de México fray Alonso de Montúfar sobre lo que toca a México y Santiago, Ciudad de México, 10 de abril de 1562, AGI, Patronato, leg. 182, ramo 2.

${ }^{78}$ El Memorial que se dio por parte de los señores Visitador y oidores... Respuesta de los Religiosos de la orden de sa' fran.co, Ciudad de México, s/f. [1564?], AHN, Diversos, Colecciones, 24, n. ${ }^{\circ} 70$, f. $1 \mathrm{v}$. 
rales no estaban aun completamente operativas. El acusado alegó en su defensa que sus detractores le habían incriminado a sabiendas de que, si alcanzaba el oficio de gobernador, él tendría después que «castigar é corregir á esos que contra mí han depuesto sus eccesos é malas costumbres, como ellos lo saben lo he hecho, é corregir, é castigar, todo» ${ }^{79}$. Por otra parte, en la querella que los maceguales e indios oficiales de artes mecánicas de la ciudad de México presentaron entre 1564 y 1568 contra sus propios oficiales de república, siete de los dieciocho cargos se refirieron, precisamente, a la práctica de malos usos y costumbres entre gobernadores, alcaldes, regidores y principales indígenas. Se alegó, por ejemplo, que cuando los dignatarios «oyen de algun negoçio [judicial] tienen por costumbre de rreçibir paga de ambas partes» y que «los dhos. alcaldes y rregidores tienen de uso y costumbre..., oyen de negoçios a los pleytantes [en sus domicilios]» ${ }^{80}$. Según los querellantes, durante los óbitos privados y las celebraciones públicas los mandatarios indígenas iban

... a casa del dho. difunto a comer y beber como fue uso y costumbre del siglo pasado... [y] tienen de costumbre en los mitotes que se hazen se visten y componen de unos trajes y devisas que eran costumbre de ponerse e vestirse aquellos viejos antepasados cuando yvan a ydolatrar e hazer sacrificio ${ }^{81}$.

Del mismo modo, les fue reprochado a los alcaldes y regidores tener «por $\mathrm{vi}^{\circ}$ [vicio] y costumbre entrar dentro en los tamazcales... rrebueltos con mugeres desnudos en queros $\rangle^{82}$.

El argumentum ad antiquitatem también fue usado interesadamente por estos mismos cabildantes nahuas de la ciudad de México en 1566 para referirse a tan sólo unas cuantas décadas anteriores a la fecha de la carta. Ante el proceso de secularización diocesana, se suplicó que, en vista de que «después q' se fundo esta çiudad, en san xusepe ques ntra. capilla tan antigua..., V. Magt. mande q' no se haga novedad en manera alguna pues los frailes nos enseñan sin ynterese alguno y los clérigos lo an todo por ynterese ${ }^{83}$. Cuatro años más tarde, los señores y principales nativos de México, Texcoco, Tacu-

79 Proceso inquisitorial..., 2009: 87. La narrativa judicial y las técnicas discursivas utilizadas en este proceso son abordadas por David Tavárez (2011: 43-48).

${ }^{80}$ Los yndios offiçiales de la parte de mexico en la querella que tenemos dada contra los alcaldes y rregidores, Ciudad de México, 02 de marzo de 1564 - 20 de julio de 1568, AGN, Civil, vol. 644, exp. 1, f. 2 r.

${ }^{81}$ Idem.

${ }^{82}$ Idem.

${ }^{83}$ Nueva España // De los all.des y regidores y prinçipales de la p.te de mexico, Ciudad de México, 25 de marzo de 1566, AGI, México, leg. 94, n. ${ }^{\circ}$. 10: ff. 1r-2v. 
ba y Tlaxcala reiteraban que, si se procedía finalmente a la uniformización feligresa entre indígenas, españoles, mestizos, negros y mulatos, se corría el riesgo de que «se corromperían [sus] buenas costumbres y policía y aun la cristiandad ${ }^{84}$. No sorpresivamente, en 1574 , los cabildantes tenochcas redundaron en que las capillas de indios y escuelas atriales de las órdenes regulares, como la de San José de los Naturales en la ciudad de México, eran indispensables porque «allí se enseñan nros. hijos la doctrina christiana y a leer y escrevir y en buenas costumbres $\rangle^{85}$.

En paralelo, resulta algo atípica la forma en que el procurador de la ciudad de Mérida y de los encomenderos de Yucatán se apropió del concepto de costumbre indígena para abogar a favor del uso de los indios tamemes en el transporte del tributo y otras mercancías. En el interrogatorio de los testigos, el procurador pretendió mostrar que era «costumbre naturalmente de los indios naturales de estas provincias de tiempo inmemorial cargarse voluntariamente con sus bastimentos y con sus mercadurías y tratos de unas partes a otras en mucha distancia de leguas $\rangle^{86}$. En cambio, el defensor de indios insistió en la normativa real que prohibía el uso de tamemes y dejó entender que su incumplimiento comprometía la credibilidad del monarca entre la población indígena. No resulta casual, por ende, que el testigo don Francisco Pech declarara que «sabe y ha entendido todas las prohibiciones que se han traído de Castilla y de México en favor de los naturales, especialmente en lo que toca a los tamemes $\rangle^{87}$. En la metrópoli, donde el expediente llegó en grado de apelación, el procurador Alonso de Herrera, encargado de representar a los encomenderos, pidió «que se guarde y cumpla la orden y costumbre que hasta aquí se

84 "Carta de los señores y principales de las provincias y ciudades de la Nueva España más principales, para el rey don Don Felipe, nuestro señor, en que piden ser desagraviados en las cosas aquí contenidas", Ciudad de México, 25 de febrero de 1570, citado por García Icazbalceta, 1892: 132. Esta carta es un trasunto de una epístola escrita en náhuatl. Se menciona, en esta última, un interesante pasaje narrativo mediante el verbo «tlatlamantitiuh»; es decir, «se usaba, se tenía orden», Newberry Library, Chicago (NL), Ayer Collection, mss. 1481, F(3a): f. 2v.

${ }^{85}$ Memoria de las cosas que los yndios principales y n.ales de la Ciudad de México pedimos y suplicamos a su mag.d el Rey don filipe n.ro señor pa' n.ra x'piandad y quietud esp.ual, Ciudad de México, 13 de marzo de 1574. Inserto en Carta del fray miguel de navarro, comisario general de los franciscanos, dirigida a Felipe II, con dos memorias redactadas por los indios principales de México, Ciudad de México, 29 de marzo de 1574, AGI, México, leg. 282, n. ${ }^{\circ}$ 54: f. 646r.

86 "Octava pregunta del interrogatorio presentado en la probanza de la ciudad de Mérida", en Querella de Francisco Palomino, protector de los indios de Yucatán, con la ciudad de Mérida y los encomenderos sobre que no se carguen los indios, 1573-1579, AGI, Justicia, leg. 1016, n. ${ }^{\circ}$ 10: f. 1066v.

87 "Respuesta de don Francisco Pech", Ibidem: ff. 1020v-1021v. 
ha tenido sobre el cargar de los dichos tributos», mientras que Sebastián de Santander, que representaba a los indios, suplicó que se diera una cédula «para que el dicho gobernador ejecute luego el dicho auto y cumpla las cédulas que están dadas ${ }^{88}$. A fin de cuentas, lo que estaba en disputa era la interpretación de la costumbre, entendida como expresión de la normativa emanada de una comunidad de personas, frente a la letra de ley, asociada con la potestad del monarca como supremo legislador del reino.

\section{CONSIDERACIONES FINALES}

El presente trabajo ha mostrado cómo en la Nueva España temprana el término «costumbres» fue utilizado para describir las leyes prehispánicas, realizándose de esta manera una operación de reducción del significado que participó, junto a otros mecanismos - como la destrucción de los registros escritos tradicionales y la difusión de «ordenanzas para pueblos de indios»—, en el proceso de erradicación de los antiguos órdenes normativos y su sustitución por la policía cristiana. El análisis ha puesto, asimismo, de manifiesto los criterios que fueron establecidos para que determinados «usos» llegaran a ser reconocidos como costumbres y que éstas, a su vez, adquiriesen pleno valor legal. Mientras que, en el primer caso, se recurrió a las nociones de antigüedad y de común aceptación de las prácticas sociales indígenas, en el segundo se apeló al derecho natural y al derecho común. Si bien en las jurisdicciones administradas por los cabildos nativos existió un control más tenue, en los demás tribunales novohispanos el «arbitrio» del juez incitó hacia un elevado nivel de imprevisibilidad. En consecuencia, hemos advertido de qué manera acabó primando la circunstancialidad ante la amplia diversidad de prácticas y hábitos culturales entre los indígenas.

Nuestro análisis converge, por consiguiente, con la propuesta que ofrece la antropóloga Deborah Poole cuando denuncia el carácter «ambiguo» del concepto de costumbre, tal como los Estados nacionales de América Latina lo emplean aún en la actualidad. Según Poole, «la figura de lo consuetudinario toma sentido dentro de las reformas neoliberales... por la flexibilidad que la categoría ofrece al Estado en sus relaciones con poblaciones marginales» ${ }^{89}$. Apoyándose en el ejemplo de los jueces de paz en el Perú contemporáneo, Poole también

88 "Alonso de Herrera en nombre del consejo, justicia y regimiento de la ciudad de Mérida", Madrid, 1576, Ibidem: f. 875r. "Sebastián de Santander en nombre de Francisco Palomino protector y defensor de los indios de Yucatán", Madrid, 1576, Ibidem: f. 876r.

${ }^{89}$ Poole, 2006: 10. 
insiste en la ausencia de estipulación alguna sobre qué «tradiciones» deberían ser aplicadas e interpretadas y cómo hacerlo ${ }^{90}$. Para la autora, el Estado neoliberal busca crear un «espacio de ilegibilidad..., donde las poblaciones marginales asumen la responsabilidad de sus vidas (y su futuro), pero siempre con la amenaza de que el Estado los pueda desconocer si sus «costumbres» les resultan inconvenientes o «ilícitas»»» ${ }^{91}$. El terreno quebradizo de ambigüedad que describe Poole presenta, sin duda alguna, similitudes evidentes con las incertidumbres que menoscabaron la fuerza de la costumbre indígena como fuente de derecho en la primera infancia de la Nueva España, tal y como ha quedado reflejado tras el examen de los pleitos descritos, del corpus de ordenanzas ( $c a$. $1537,1546,1583)$ y de los cuestionarios de 1573 y 1577.

La indefinición y la ausencia de patrones jurídicos diáfanos invitaron a la continua apertura de nuevas prácticas y a la caída en desuso de otras. En este sentido, los mecanismos descritos en el presente trabajo pueden equipararse a la «invención de la tradición», descrita por Eric Hobsbawm, en la medida en que usos y costumbres sirvieron como herramienta de legitimación en escenarios de crisis, reacomodación y cambio de ciclo hegemónico ${ }^{92}$. En resumidas cuentas: en la Nueva España de la post-conquista, la conveniente reconversión de los antiguos órdenes normativos indígenas en una nueva especificidad identitaria, jurídica e institucional entre los naturales, sujeta a la Corona española, constituyó una fuente de cimentación para la proyección imperial en América de la monarquía compuesta y de su doctrina del dominium politicum et regale ${ }^{93}$. Como hemos visto, la integración de aquellas prácticas autóctonas al orden legal estuvo siempre sometida a poderes sancionadores externos. Y esto nos retrotrae al texto constitucional citado en la introducción, en su invocación al derecho federal y al derecho internacional, concebidos como límites al reconocimiento de las costumbres indígenas.

90 Ibidem: 15-16. La autora señala que imprecisiones semejantes se observan en las reformas realizadas en el Estado de Oaxaca (México) en los años 1990 para «garantizar» el derecho a elegir las autoridades municipales según los «usos y costumbres» locales.

91 Ibidem: 18.

92 Hobsbawm, 2002: 7-21.

93 Esta doctrina, bien conocida mediante la tratadística jurídica inglesa o la experiencia castellanoleonesa y aragonesa, exhibiría, así, un cierto grado de sustancialidad en las Indias novohispanas. Koenigsberger, 1984: 87-120. Elliott, 1992: 48-71. Osborne, 2000: 161-187. Para el caso castellanoleonés y aragonés, ver Hesles Bernal, 2005: 29-61. 


\section{BIBLIOGRAFÍA}

Alberte González, Antonio, “Cicerón y Quintiliano ante los principios analogistas y anomalistas", Minerva: Revista de filología clásica, 1 (Valladolid, 1987): 117-128.

Alfonso X, Las Siete Partidas del muy noble rey Don Alfonso el Sabio: Glosadas por el Lic. Gregorio López, del Consejo Real de Indias de S. M. Tomo I, que contiene la 1. ${ }^{a}$ y 2. ${ }^{a}$ Partida, Madrid, Compañía General de Impresores y Libreros del Reino, 1843.

Alva Ixtlilxóchitl, Fernando de, Historia de la nación chichimeca, Madrid, Dastin, 2000 [ca. 1620].

Aragón Andrade, Orlando, "Los sistemas jurídicos indígenas frente al derecho estatal en México. Una defensa del pluralismo jurídico", Boletín Mexicano de Derecho Comparado, XL/118 (México D. F., 2007): 9-26.

Argüello Solórzano, Federico y Molina Argüello, Carlos (comps.), Monumenta Centroamericae historica: colección de documentos y materiales para el estudio de la historia y de la vida de los pueblos de la América Central, Managua, Instituto Centroamericano de Historia / Universidad Centroamericana, 2000 [1965], vol. 3.

Arzápalo Marín, Ramón (ed.), Calepino de Motul. Diccionario Maya-Español, México D. F., UNAM, 1995, 2 vols.

Bejarano Galdino, Emilio, "El almotacén como institución armonizadora de las relaciones sociales", Bolletí de la Societat Arqueològica Lul·liana: Revista d'estudis històrics, 56 (Palma de Mallorca, 2000): 243-260.

Bernardino de Sahagún, Colloquios y doctrina cristiana: con que los doce frailes de San Francisco, enviados por el papa Adriano VI y por el emperador Carlos V, convirtieron a los indios de la Nueva España. En lengua mexicana y española. Los diálogos de 1524, editado por Miguel León-Portilla, México D. F., IIH, UNAM, 1986 [1564].

Bernardino de Sahagún, Historia general de las cosas de la Nueva España, Madrid, Editorial Dastin, 2003 [1577], 2 vols.

Bonmatí Sánchez, Virginia, "Norma y uso según Quintiliano", Revista española de lingüística, 18/2 (Madrid, 1988): 343-346.

Brian, Amber E., Alva Ixtlilxochitl's Native Archive and the Circulation of Knowledge in Colonial Mexico, Nashville, Vanderbilt University Press, 2016.

Brinton, Alan, "Quintilian, Plato, and the Vir Bonus", Philosophy \& Rhetoric, 16/3 (Harrisburg, 1983): 167-184.

Canet Aparisi, Teresa, Vivir y pensar la política en una monarquía plural: Tomás Cerdán de Tallada, Valencia, Universitat de València, 2009. 
Carreño, Alberto María, Un desconocido cedulario del siglo XVI perteneciente a la Catedral Metropolitana de México, México D. F., Ediciones Victoria, 1944.

Casas, Bartolomé de las, De thesauris, Madrid, Alianza, 1992 [1563].

Cedulario Índico de Manuel José de Ayala, Madrid, Real Biblioteca del Palacio Real de Madrid, 1773-1793.

Celestino Solís, Eustaquio y Reyes García, Luis (eds. y trads.), Anales de Tecamachalco, 1398-1590, México D. F., CIESAS, 1992 [ca. 1590].

Christensen, Mark Z., Nahua and Maya Catholicisms: Texts and Religion in Colonial Central Mexico and Yucatan, Stanford, Stanford University Press, 2013.

Christensen, Mark Z., Translated Christianities: Nahuatl and Maya Religious Texts, University Park, The Pennsylvania State University Press, 2014.

Cicerón, Marco Tulio, De finibus bonorum et malorum, editado por L. D. Reynolds, Oxford, Clarendon Press, 1988 [ca. 45 a.C.].

CODOIN, Colección de documentos inéditos para la historia de España, Madrid, Imprenta de la Viudad de Calero, 1842-1896.

Covarrubias, Sebastián de, Tesoro de la Lengua castellana o española, Madrid, Editorial Castalia, 1995 [1611].

Cunill, Caroline, "La circulación del derecho indiano entre los mayas: escritura, oralidad y orden simbólico en Yucatán, siglo XVI", Jahrbuch für Geschichte Lateinamerikas, 52 (Berlín, 2015): 15-36.

Cunill, Caroline, "L'accès des Indiens à la justice du roi dans les questionnaires de 1573 y 1577 et leur reflet dans les Relations géographiques du Yucatán”, Pierre Ragon y Arnaud Exbalin (coords.), Le roi de justice au Nouveau Monde: lien de fidélité et pratiques judiciaires (XVI ${ }^{e}-X V I I I^{e}$ siècle), París, Université de Paris X, 2020: 47-68.

Daston, Lorraine y Stolleis, Michael (eds.), Natural Law and Laws of Nature in Early Modern Europe: Jurisprudence, Theology, Moral, and Natural Philosophy, Londres / Nueva York, Routledge, 2016.

Dibble, Charles E., "Los Manuscritos de Tlatelolco y México y el Códice Florentino", Estudios de Cultura Náhuatl, 29 (México D. F., 1999): 27-64.

Domingo, Rafael, "El binomio «auctoritas-potestas» en el Derecho Romano y Moderno". Persona y Derecho, 37 (Pamplona, 1997): 183-196.

Elliott, John H., "A Europe of Composite Monarchies", Past \& Present, 137/1 (Oxford, 1992): 48-71.

Encinas, Diego de, Cedulario Indiano, editado por Alfonso García Gallo, Madrid, Real Academia de la Historia, 1945 [1596], 4 libros. 
Estruch, Dolores, «"Entre la Potestas y la Auctoritas”. Un recorrido histórico por el dualismo de poder en el occidente cristiano», Revista Cultura y Religión, 6/2 (Tarapacá, 2012): 78-102.

Fernández de Navarrete, Martín (coord.), Colección de los viajes y descubrimientos que hicieron por mar los españoles desde finales del siglo $X V$, Madrid, Imprenta Nacional, 1859, tomo II.

Fernando III, Fuero Juzgo. Colección de códigos y leyes de España. Primera sección. Códigos antiguos. Tomo I, Madrid, Imprenta de Francisco Roig, 1865.

Flores García, Fernando, La administración de justicia en los pueblos aborígenes de Anáhuac, México D. F., IIJ / UNAM, 2007.

García, Manuel, "La Alfaquequería Mayor de Castilla en Andalucía a fines de la Edad Media. Los alfaqueques reales", José Enrique López de Coca (ed.), Estudios sobre Málaga y el Reino de Granada en el V Centenario de la Conquista, Málaga, Excelentísima Diputación Provincial de Málaga, 1987: 37-54.

García Bernal, Manuela Cristina, "García Palacio y sus ordenanzas para Yucatán”, Temas Americanistas, 5 (Sevilla, 1985): 1-12.

García Icazbalceta, Joaquín (ed.), Códice Mendieta, México D. F., Editorial Díaz de León, 1892.

Gil, Fernando, «Las "juntas eclesiásticas” durante el episcopado de Fray Juan de Zumárraga (1528-1548)», Teología: Revista de la Facultad de Teología de la Pontificia Universidad Católica Argentina, 54 (Buenos Aires, 1989): 7-34.

Giraudo, Laura, “¿Retornos del Antiguo Régimen?: costumbre y derecho indígena”, Laura Giraudo (ed.), Ciudadanía y derechos indígenas en América Latina: poblaciones, estados y orden internacional, Madrid, Centro de Estudios Políticos y Constitucionales, 2007: 39-48.

González Sopeña, Inmaculada, "Arabismos y fiscalidad en el Reino de Granada”, Dicenda. Cuadernos de Filología Hispánica, 35 (Madrid, 2017): 109-130.

Graubart, Karen A., "Learning from the Qadi: The Jurisdiction of Local Rule in the Early Colonial Andes", Hispanic American Historical Review, 95/2 (Durham [EUA], 2015): 195-228.

Hanks, William F., Converting Words. Maya in the Age of the Cross, Berkeley, University of California Press, 2010.

Hernando Sánchez, Carlos José, Las Indias en la Monarquía Católica: Imágenes e ideas políticas, Valladolid, Universidad de Valladolid, 1996.

Herzog, Tamar, "Colonial Law and «Native Customs»: Indigenous Land Rights in Colonial Spanish America”, The Americas, 69/3 (Cambridge, 2013): 303-321.

Herzog, Tamar, "Immemorial (and Native) Customs in Early Modernity: Europe and the Americas", Comparative Legal History, 9/1 (Cheltenham, 2021): 1-53. 
Hesles Bernal, José Carlos, El vuelo de Astrea: Configuración jurídico-política de la Monarquía Católica, México D. F., Porrúa / Facultad de Derecho / UNAM, 2005.

Hobsbawm, Eric, "Introducción: la invención de la tradición”, Eric Hobsbawm y Terence Ranger (eds.), La invención de la tradición, Barcelona, Crítica, 2002 [1983]: 7-21.

Jiménez Bartlett, Lelia, "Las autonomías indígenas como formas de pluralismo jurídico", Ius, Revista del Instituto de Ciencias Jurídicas de Puebla A.C., 22 (Puebla de Zaragoza, 2008): 247-270.

Jiménez Estrella, Ángel, "Nobleza y servicio político a la monarquía en el siglo XVI: los Mendoza y su vinculación al Reino de Granada", Obradoiro de Historia Moderna, 18 (Santiago de Compostela, 2009): 211-232.

Karttunen, Frances E., An Analytical Dictionary of Nahuatl, Norman, University of Oklahoma Press, 1992.

Koenigsberger, Helmut G., "Dominium regale o dominium politicum et regale: monarquías y parlamentos en la Europa moderna", Revista de las Cortes Generales, 3 (Madrid, 1984): 87-120.

Konetzke, Richard, Colección de documentos para la historia de la formación social de Hispanoamérica, 1493-1810, Madrid, CSIC, 1953.

Lacadena, Alfonso, "Regional Scribal Traditions: Methodological Implications for the Decipherment of Nahuatl Writing", PARI Journal, VIII /4 (Washington D. C., 2008): 1-22.

Laird, Andrew, “Universal History and New Spain's Indian Past: Classical Knowledge in Nahua Chronicles", Bulletin of Latin American Research. Journal of the Society of Latin American Studies, 37/1 (Hoboken, 2018): 86-103.

Landa, Diego de, Relación de las cosas de Yucatán, Barcelona, Linkgua, 2019 [1566].

Leeming, Ben, “A Nahua Christian Talks Back: Fabián de Aquino’s Antichrist Dramas as Autoethnography", David Tavárez (ed.), Words \& Worlds Turned Around: Indigenous Christianities in Colonial Latin America, Boulder, University of Colorado Press, 2017: 172-192.

León-Portilla, Miguel, "La autonomía indígena: Carta al Príncipe Felipe de los principales de México en 1554", Estudios de Cultura Náhuatl, 32 (México D. F., 2001): 235-256.

León-Portilla, Miguel, La filosofía náhuatl estudiada en sus fuentes, México D. F., IIH, UNAM, 2006 [1956].

Lockhart, James, The Nahuas after the Conquest. A Social and Cultural History of the Indians of Central Mexico, Sixteenth through Eighteenth Century, Palo Alto, Stanford University Press, 1992. 
Lockhart, James, "Double Mistaken Identity: Some Nahua Concepts in Postconquest Guise", James Lockhart (ed.), Of Things of the Indies: Essays Old and New in Early Latin American History, Stanford, Stanford University Press, 1999: 98-119.

Luque Talaván, Miguel, Un universo de opiniones. La literatura jurídica indiana, Madrid, Instituto de Historia-CSIC, 2003.

Macías Hernández, Antonio M., "La colonización europea y el derecho de aguas. Un ejemplo de Canarias, 1480-1525”, Hispania. Revista Española de Historia, LXIX/233 (Madrid, 2009): 715-738.

Malagón Pinzón, Miguel Alejandro, "La ciencia de la policía y el proceso de civilización de indígenas", Manuel Alberto Restrepo Medina (ed.), El derecho administrativo en los albores del siglo XXI, Bogotá, Universidad del Rosario, 2007: 131-147.

Manzano Manzano, Juan, "Las leyes y costumbres indígenas en el orden de prelación de fuentes del Derecho Indiano", Revista del Instituto de Historia del Derecho Ricardo Levene, 18 (Buenos Aires, 1967): 13-64.

Mas Torres, Salvador, Ethos y pólis: Una historia de la filosofía práctica en la Grecia clásica, Madrid, Istmo, 2003.

Meccarelli, Massimo (coord.), Diversitá e discorso giuridico. Temi per un dialogo interdsicplinare su diritti e giustizia in tempo di transizione, Madrid, Editorial Dykinson, 2016.

Menegus Bornemann, Margarita, "La costumbre indígena en el derecho indiano, 1529-1550", Anuario Mexicano de Historia del Derecho, 4 (México D. F., 1992): 151-159.

Miceli, Paola, Derecho consuetudinario y memoria. Práctica jurídica y costumbre en Castilla y León (siglos XI-XIV), Madrid, Universidad Carlos III de Madrid, 2012.

Molina, Alonso, Vocabulario en lengua castellana y mexicana, Ciudad de México, Casa de Antonio Espinola, 1571.

Muñoz Arbeláez, Santiago, Costumbres en disputa. Los muiscas y el Imperio español en Ubaque, siglo XVI, Bogotá, Universidad de los Andes, 2015.

Nieto, Alejandro, "Algunas precisiones sobre el concepto de policía", Revista de administración pública, 81 (Madrid, 1976): 35-75.

O’Gorman, Edmundo, "Una ordenanza para el gobierno de los indios, 1546”, Boletín del Archivo General de la Nación, 11/2 (México, D. F., 1940): 179-194.

Olko, Justyna, "The Nahua Story of Judas: Indigenous Agency and Loci of Meaning", David Tavárez (ed.), Words \& Worlds Turned Around: Indigenous Christianities in Colonial Latin America, Boulder, University of Colorado Press, 2017: 150-171. 
Olko, Justyna y Brylak, Agnieszka, "Defending Local Autonomy and Facing Cultural Trauma: A Nahua Order against Idolatry, Tlaxcala, 1543", Hispanic American Historical Review, 98/4 (Durham [EUA], 2018): 574-575.

Osborne, Thomas M., "Dominium regale et politicum: Sir John Fortescue's Response to the Problem of Tyranny as Presented by Thomas Aquinas and Ptolemy of Lucca", Mediaeval Studies, 62 (Toronto, 2000): 161-187.

Otte, Enrique, "La despoblación de La Española: la crisis de 1528", Ibero-amerikanisches Archiv, 10/3 (Berlín, 1984): 241-265.

Owensby, Brian P., "Pacto entre rey lejano y súbditos indígenas. Justicia, legalidad y política en Nueva España, siglo XVII", Historia Mexicana, LXI/1 (México D. F., 2011): 59-106.

Pérez-Delgado, Esteban, Moral de convicciones, moral de principios: Una introducción de la ética desde las ciencias sociales, Salamanca / Madrid, San Esteban / Edibesa, 2000.

Petit Calvo, Carlos, "Consuetudo y mos en la Lex Visigothorum", Anuario de historia del derecho español, 54 (Madrid, 1984): 209-252.

Pollnitz, Aysha, "Old Words and the New World: Liberal Education and the Franciscans in New Spain, 1536-1601", Transactions of the Royal Historical Society, 27 (Cambridge, 2017): 123-152. Ganador del Whitfield Prize.

Poole, Deborah, "Los usos de la costumbre. Hacia una antropología jurídica del Estado neoliberal", Alteridades, 16/31 (México D. F., 2006): 9-21.

Premo, Bianca, "Custom Today: Temporary, Customary Law, and Indigenous Enlightenment", Hispanic American Historical Review, 94/3 (Durham [EUA], 2014): 355-379.

Proceso inquisitorial contra el cacique de Tetzcoco, editado por Eusebio Goméz de la Puente, México D. F., Publicaciones del AGN, 2009 [1910].

Puente Luna, José Carlos de la y Honores, Renzo, "Guardianes de la real justicia: alcaldes de indios, costumbre y justicia local en Huarochirí colonial", Revista Histórica, 40/2 (Lima, 2016): 11-47.

Puga, Vasco de, Provisiones, cedulas, instrucciones de Su Magestad, ordenanças de difuntos y audiencia para la nueva expedición de los negocios y administracion de justiçia y governacion de esta Nueva España, y para el buen tratamiento y conservacion y los yndios desde el año 1525 hasta este presente de 63, Bloomington, Universidad de Indiana, 2012 [1563].

Quijano, Francisco, "Ser libre bajo el poder del rey. El republicanismo y constitucionalismo de Bartolomé de las Casas", Historia Mexicana, 65/1 (México D.F., 2015): 7-64. 
Quijano, Francisco, Las repúblicas de la monarquía. Pensamiento constitucionalista y republicano en Nueva España, 1550-1610, México D. F., IIH, UNAM, 2017.

Recopilación de las Leyes de los Reinos de Indias, Madrid, Julián de Paredes Impresor, 1681.

Reyes García, Luis (ed.), Documentos sobre tierras y señorío en Cuauhtinchan, México D. F., INAH / CIESAS / Gobierno del Estado de Puebla, 1978.

Reyes García, Luis, "Los autores, el lugar y la fecha de la escritura", Luis Reyes García (ed.), ¿Cómo te confundes? ¿Acaso no somos conquistados? Anales de Juan Bautista, México D. F., CIESAS / Biblioteca Lorenzo Boturini de la Insigne / Nacional Basílica de Guadalupe, 2001: 27-28.

Rovira Morgado, Rossend, San Francisco Padremeh: El temprano cabildo indio y las cuatro parcialidades de México-Tenochtitlan (1549-1599), Madrid, CSIC, 2017.

Rovira Morgado, Rossend y Fracas, Simone, "From huey altepemeh to civitates christianae: Considering a Franciscan collective agency project on Indian cathedral cities in post-Tridentine Central Mexico (1567-1585)", Colonial Latin American Review, 27/2 (Londres, 2018): 178-202.

Sáez, José Luis, Don Sebastián Ramírez de Fuenleal: Obispo y legislador, Santo Domingo, Editora Amigo del Hogar, 1996.

Schiller, Arthur A., Roman Law: Mechanisms of Development, Nueva York, Mouton Publishers, 1978.

Schroeder, Susan, "The Truth about the Crónica Mexicayotl", Colonial Latin American Review, 20/2 (Londres, 2011): 233-247.

Sell, Barry D. y Kellogg, Susan, "We want to give them laws: Royal Ordinances in a Mid-Sixteenth Century Nahuatl Text”, Estudios de Cultura Náhuatl, 27 (México D. F., 1997): 325-367.

Solano, Francisco de (ed.), Cuestionarios para la formación de las relaciones geográficas de Indias, siglos XVI-XIX, Madrid, CSIC, 1988.

Strecker, Matthias y Artiega, Jorge, “La «Relación de Algunas Costumbres (1582)» de Gaspar Antonio Chi”, Estudios de Historia Novohispana, 6 (México D. F., 1978): 1-21.

Tau Anzoátegui, Víctor, "La costumbre como fuente del Derecho indiano en los siglos XVI y XVII: estudio a través de los Cabildos del Río de la Plata, Cuyo y Tucumán”, Actas del III Congreso del Instituto Internacional de Historia del Derecho Indiano, Madrid, Instituto Nacional de Estudios Jurídicos, 1973: 115-192.

Tavárez, David, The Invisible War: Indigenous Devotions, Discipline, and Dissent in Colonial Mexico, Stanford, Stanford University Press, 2011. 
Teuscher, Simon, "Document collections, mobilized regulations, and the making of customary law at the end of the Middle Ages", Archival Science, 10 (Londres, 2010): 211-229.

Tezozómoc, Hernando de Alvarado, Crónica mexicáyotl, México D. F., IIH, UNAM, 1998 [1949].

Torquemada, Juan de, Monarquía Indiana, México D. F., IIH, UNAM, 1973-1985 [1615].

Vallen, Nino, "Healing Power: Land-Surveying Politics and the Archive of Mendoza's America (1535-1552)", Romy Köhler y Anne Ebert (eds.), Las agencias de lo indígena en la larga era de la globalización. Microperspectivas de su producción y representación desde la época colonial temprana hasta el presente, Berlín, Ibero-Amerikanisches Institut, 2015: 77-98.

Vargas Valencia, Aurelia, Las «Institutiones» de Justiniano en Nueva España, México D. F., UNAM, 2001.

Velasco Gómez, Ambrosio (coord.), Significación política y cultural del humanismo iberoamericano en la época colonial, México D. F., UNAM / Plaza y Valdés, 2008.

Vicente, Enrique (ed.), El Digesto del Emperador Justiniano, Madrid, Establecimiento Tipográfico de Enrique Vicente, 1878.

Vincent, Bernard, "Las rentas particulares del Reino de Granada en el siglo XVI: fardas, habices, hagüela", Bernard Vincent (ed.), Andalucía en la Edad Moderna: economía y sociedad, Granada, Excelentísima Diputación Provincial de Granada, 1985: 81-122.

Warren, Benedict J., Vasco de Quiroga en África, Morelia, Fimax, 1998.

Yannakakis, Yanna, "Costumbre: A Language of Negotiation in Eighteenth-Century Oaxaca", Ethelia Ruiz Medrano y Susan Kellogg (eds.), Negotiation within Domination. New Spain's Indian Pueblos Confront the Spanish State, Boulder, University Press of Colorado, 2010: 37-173.

Zantwijk, Rudolf Van, "In ihiyoyaoyotl in atl in tlachinolli teoyotica", Estudios de Cultura Náhuatl, 1 (México D. F., 1959): 113-124.

Zorita, Alonso, Los señores de la Nueva España, Ethelia Ruiz Medrano (ed.), México D. F., UNAM, 1993.

Fecha de recepción: 17 de septiembre de 2019.

Fecha de aceptación: 18 de enero de 2020. 


\section{"What our parents and grandparents left us": rhetoric and procedural praxis in indigenous 'uses and customs' $>$ in early New Spain}

This paper aims to explore the manifold meanings of the concept "uses and customs" in the context of the cultural and political reorganization of Central Mexico and Yucatán in the sixteenth century. A wide range of sources have been analysed, including colonial dictionaries, the pastoral and indoctrination manuals of missionaries, lawsuits, and legal ordinances issued to local native governorships. We conclude that the high degree of conceptual and practical flexibility of this legal concept contributed both to the consolidation of colonial domination and to the endorsement of certain demands made by the indigenous authorities.

Key words: Uses and customs; Indian communities; Colonial legal culture; Central Mexico; Yucatán. 
